\title{
Advanced High Power DC-DC Converter using A Novel Type Voltage Source Full-Bridge Soft Switching PWM Inverter with High Frequency Transformer Link for Arc Welding Applications
}

\author{
Keiki Morimoto, Member, Toshimitsu Doi, Member, Haruhiko Manabe, Member (DAIHEN Corporation) \\ Tarek Ahmed, Student Member, Eiji Hiraki, Member (Yamaguchi University) \\ Hyun-Woo Lee, Member, Mutsuo Nakaoka, Member (Kyungnam University)
}

Keywords: DC-DC power converter, high frequency transformer link, soft switching PWM arc welding machine

\section{Circuit Operation}

Figure 1 shows the proposed soft switching PWM dc-dc power converter using a novel type full-bridge soft switching PWM inverter with high frequency transformer, which is based upon auxiliary active resonant dc link snubber assisted typical full-bridge inverter with a series switch in dc busline and a lossless capacitor in parallel with dc busline.

Figure 2 shows timing pattern sequences of switching gate driving pulses. The gate voltage pulse signals for the switches $\mathrm{Q}_{1}$ and $\mathrm{Q}_{4}$ or $\mathrm{Q}_{2}$ and $\mathrm{Q}_{3}$ in voltage source full-bridge inverter arms are the same as PWM signal sequences of conventional full-bridge inverter. The turn-on gate voltage pulse signal to the dc busline side series switch $Q_{5}$ is applied to $Q_{5}$ at the same timing as the turn-on signals to $\mathrm{Q}_{1}$ and $\mathrm{Q}_{4}$ or $\mathrm{Q}_{2}$ and $\mathrm{Q}_{3}$. The turn-off signal to $\mathrm{Q}_{5}$ is delivered to $\mathrm{Q}_{5}$ before the predetermined length $t_{a}$ with respect to the time when the turn-off signals are applied to $\mathrm{Q}_{1}$ and $\mathrm{Q}_{4}$ or $\mathrm{Q}_{2}$ and $\mathrm{Q}_{3}$.

The switches $\mathrm{Q}_{1}\left(\mathrm{~S}_{1} / \mathrm{D}_{1}\right)$ and $\mathrm{Q}_{4}\left(\mathrm{~S}_{4} / \mathrm{D}_{4}\right)$ or $\mathrm{Q}_{2}\left(\mathrm{~S}_{2} / \mathrm{D}_{2}\right)$ and $\mathrm{Q}_{3}\left(\mathrm{~S}_{3} / \mathrm{D}_{3}\right)$ in the inverter arms can perform ZVS turn-off due to the existence of the PWM switch $\mathrm{Q}_{5}\left(\mathrm{~S}_{5} / \mathrm{D}_{5}\right)$ and the quasi resonant capacitor $\mathrm{C}$ which is completely discharged before the switches $\mathrm{Q}_{1}$

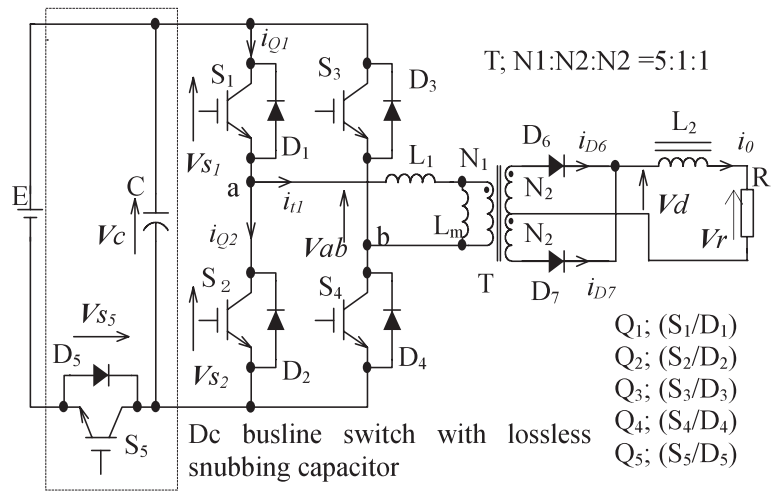

Fig. 1. Soft switching PWM high frequency inverter fed dc-dc converter circuit

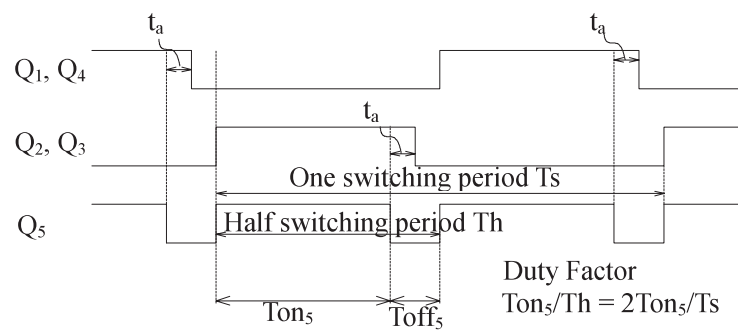

Fig. 2. Pattern sequences of switching gate driving pulses and $\mathrm{Q}_{4}$ or $\mathrm{Q}_{2}$ and $\mathrm{Q}_{3}$ in the inverter arms are turned off. In addition, the inverter switches can also perform ZCS at a turn-on with the aid of inductance $\mathrm{L}_{1}$, as a parasitic leakage inductance of high frequency transformer.

As for the PWM switch $\mathrm{Q}_{5}$ in series with the dc busline, the controlled switch can achieve ZVS at turn-off due to quasi resonant capacitor $\mathrm{C}$. This switch $\mathrm{Q}_{5}$ can also achieve ZVS/ZCS at turn-on due to $\mathrm{L}_{1}$ and $\mathrm{C}$, which has been charged up to the same voltage as the dc supply by the energy storage in the $\mathrm{L}_{1}$ after the inverter switches are turned off completely.

\section{Experimental Results}

In comparative power loss analysis illustrated in Fig. 3, the total power loss of all the bridge arm switches including dc busline switch in this soft switching dc-dc power converter circuit is compared with that of all the switches in conventional hard switching PWM converter under the condition of $32 \mathrm{~V} 300 \mathrm{~A}(=9.6 \mathrm{~kW})$ output power. The switching frequency of inverter power stage using IGBTs is designed for more than about $10 \mathrm{kHz}$. The more the switching frequency of inverter increases, the more this new dc-dc converter circuit has remarkable advantages as for efficiency and power density as compared with the conventional hard switching one.

Since the conduction power loss of additional dc busline switch in the primary circuit of transformer is increased under the newlydeveloped dc-dc converter, this new circuit topology of full-bridge soft switching PWM inverter with high frequency transformer is acceptable for low voltage and large current dc-dc power supplies such as arc welding power source from a practical point of view.

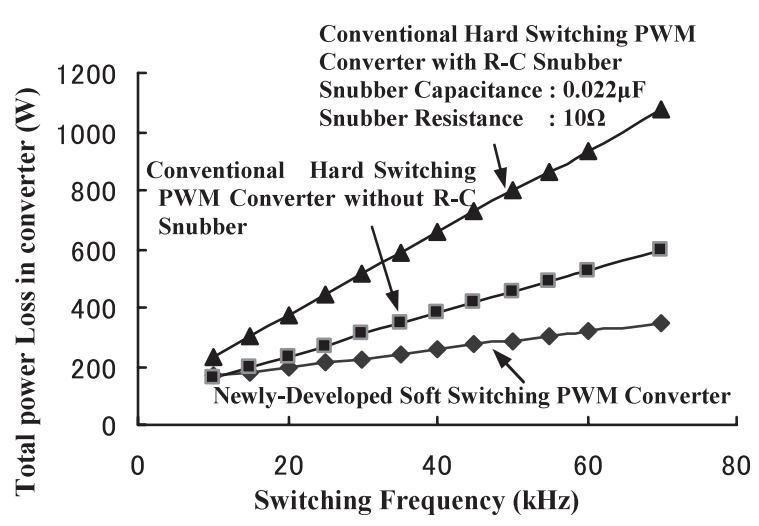

Fig. 3. Comparative power loss analysis between newly-developed soft switching PWM converter and conventional hard switching PWM dc-dc power converters 


\title{
新方式電圧給電フルブリッジ形ソフトスイッチング PWM 高周波 インバータを用いたアーク溶接機用高出力 DC-DC変換器
}

$\begin{array}{llllll}\text { 正員 } & \text { 森本 } & \text { 慶樹* } & \text { 正 員 } & \text { 土井 敏光* } \\ \text { 正 員 } & \text { 真鍋 } & \text { 陽彦* } & \text { 学生員 } & \text { Tarek Ahmed } \\ \text { 正 } & \text { 員 平木 } & \text { 英治** } & \text { 正 員 } & \text { 李 } & \text { 鉝雨*** } \\ \text { 正 員 中岡 } & \text { 睦雄 } \\ \text { *** } & & & & \end{array}$

\author{
Advanced High Power DC-DC Converter using A Novel Type Voltage Source \\ Full-Bridge Soft-Switching PWM Inverter with High Frequency Transformer Link \\ for Arc Welding Applications
}

Keiki Morimoto*, Member, Toshimitsu Doi*, Member, Haruhiko Manabe*, Member, Tarek Ahmed**, Student Member, Eiji Hiraki**, Member, Hyun-Woo Lee ${ }^{* * *}$, Member, Mutsuo Nakaoka***, Member

This paper presents a new circuit topology of full-bridge soft-switching PWM inverter linked DC-DC power converter composed of conventional full-bridge high frequency PWM inverter with high frequency transformer and an active quasi-resonant snubber consisting of an additional power switching device in series with DC busline and a lossless capacitor in parallel with DC busline. Under this proposed high frequency soft-switching PWM inverter linked DC-DC converter, four power switches in the full-bridge arms and DC busline series switch can achieve ZVS at turnoff commutation. By developing the advanced soft-switching PWM high frequency inverter type DC-DC converter, although the conduction power loss of DC busline series power switch increases a little, the total turn-off switching loss of full-bridge high frequency inverter power modules can be sufficiently lowered more and more in the higher frequency range of $60 \mathrm{kHz}$. As a result, when the switching frequency of high frequency inverter power stage using IGBT power modules is designed so as to be more than about $10 \mathrm{kHz}$, the more the switching frequency of inverter increases, the more this high frequency soft-switching DC-DC converter has remarkable advantage as for the power conversion efficiency as compared with the conventional hard-switching PWM inverter DC-DC converter. Its practical effectiveness of high power density and high performance is actually proved for TIG arc welding equipment in industry.

キーワード：フルブリッジインバータ, DC-DC コンバータ，高周波トランスリンク，直流バスライン並列追加コンデンサ， 直流バスライン直列追加スイッチ，ソフトスイッチング PWM，TIG アーク溶接機

Keywords: full-bridge inverter, DC-DC converter, high frequency transformer link, additional DC busline series switch and parallel capacitor snubber, soft-switching PWM, TIG arc welding

*(株) ダイヘン 溶接メカトロカンパニー 溶接機事業部

于 566-0021 摂津市南千里丘 5 番 1 号

Welding Engineering Department, Welding \& Mechatronics Company, DAIHEN Corporation

5-1, Minamisenrioka, Settsu 566-0021

** 山口大学工学部 ·電気電子工学科

T755-8611 宇部市常盤台

Faculty of Engineering Department of Electrical and Electronics Engineering, Yamaguchi University

Tokiwadai, Ube 755-8611

*** Electric Energy Saving Research Center, Kyungnam University, Masan, Korea

\section{1. まえがき}

近年，IGBT で代表される MOS ゲート制御パワー半導 体デバイスを用いた高周波パルス変調スイッチングモード 半導体電力変換装置（インバータ／DC-DCコンバータな ど）の高周波スイッチング技術が, その応用機器の小型軽量 化, 高性能化の実現に不可欠となっている。高周波トラン スを含む並列共振, 直列共振, 直並列共振といった共振夕 ンク方式, アクティブ補助部分共振スナバ方式, これらの 組合せになる複合共振方式によるソフトスイッチング転流 モードを取り入れたパルス幅変調高周波スイッチング電力 
変換応用技術開発が一段と進んでいる ${ }^{(1)}$ 。なかでも, TIG · $\mathrm{CO} 2 / \mathrm{MAG}$ アーク溶接機用高周波絶縁型直列共振タンクイ ンバータを用いたソフトスイッチング DC-DC コンバータ が一部実用化されている。出力 $3.9 \mathrm{~kW}$ 使用率 $30 \%$ 条件下 の直列共振タンク方式では, 質量 $2.6 \mathrm{~kg}$ といった軽量化が 図られている。目下, 溶接機用直流電源装置の小型軽量化 をターゲットとした製品開発の競争が繰り広げられている。 一方, $5 \mathrm{~kW} \sim 10 \mathrm{~kW}$ 程度の溶接機用補助部分共振スナバ方 式高周波インバータを用いたソフトスイッチング DC-DC コンバータの検討が注目される。

さらに, $10 \mathrm{~kW}$ 程度以上の中・大容量の溶接機用直流電源 として, 電圧給電フルブリッジハードスイッチング PWM イ ンバータを用いた DC-DC コンバータ電源が一般的に使用 されている。直流出力側で $300 \mathrm{~A}$ 程度以上の大電流を制御 処理する溶接機用高周波絶縁型ハードスイッチング PWM DC-DC コンバータが実用化されている。しかし，ハードス イッチング PWM 方式であるため, 使用するパワーデバイ ス IGBT のスイッチング損失が大きく，スイッチングサー ジ抑制用スナバ回路による損失も現れる上に，高い $\mathrm{dv} / \mathrm{dt}$ に伴う対地高周波漏れ電流によるコモンモード電磁ノイズ も増加する。この他, 従来からの回路卜ポロジーでは, 高 い di/dtによる高周波トランス巻線の絶縁破壊の問題も顕 在化している(2)。フルブリッジ形高周波インバータの更な る高周波スイッチング動作の実現において，アクティブ補 助部分共振スナバによるソフトスイッチング PWM DC-DC

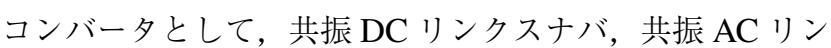
クスナバ，共振ブリッジレッグリンクスナバといったいく つかが考えられる。しかし，これらのアクティブ補助部分 共振スナバによる追加回路構成の損失増加, コスト高, 高 電力密度化の困難，センサーを含む制御系の複雑化などと

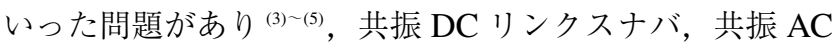
リンクスナバ，共振ブリッジレッグリンクスナバといった アクティブ補助共振スナバ方式はほとんど実用化されてい ない。目下 $10 \mathrm{kHz} \sim 20 \mathrm{kHz}$ 程度のスイッチング周波数で はハードスイッチング PWM 方式高周波インバータ絶縁型 DC-DC コンバータが使用されているのが現実である。

このハードスイッチング PWM 高周波絶縁型 DC-DC コ ンバータのスイッチング動作周波数を高周波化するため, 数 $\mathrm{kW}$ 以上を電力制御するのに適した高周波可飽和リアクトル によるパワーマグネチックスイッチを用いたソフトスイッ チング PWM DC-DC コンバータ (6) や 2 次側にパワー半導 体スイッチを挿入した 2 次側位相シフトソフトスイッチン グ PWM 高周波絶縁型部分共振 DC-DC コンバータ (7) (11) が 研究開発されている。しかし，溶接機のように高周波卜ラ ンス 2 次側出力条件が低電圧・大電流の直流電源対応では, その 2 次側に可飽和リアクトルスイッチやパワー半導体ス イッチを挿入するとその導通損失が大きくなり, ソフトス イッチングにより低減されるスイッチング損失よりも，追 加した 2 次側の可飽和リアクトルスイッチやパワー半導体 スイッチの導通損失が大きくなる。従って，溶接機のよう
な低電圧 · 大電流直流出力を必要とする直流電源では，高 周波トランス 1 次側でのソフトスイッチングを実現する方 法が適している。

そこで，筆者らは高周波トランス絶縁リンク DC-DC コ ンバータの高周波トランス 1 次側において, 電圧形フルブ リッジインバータに 1 つ直流バスライン直列追加スイッ チと直流バスライン並列追加ロスレススナバコンデンサを 用いた極めて簡単な部分共振 DCリンクスナバを用いた溶 接機用新方式部分共振ソフトスイッチング PWM 高周波イ ンバータ絶縁型 DC-DC コンバータを提案し, その回路動作 原理と特徵を述べている。次に本回路の動作特性をシミュ レーションと試作試験により図説して評価検討を行った結 果について述べている。IGBT パワーモジュールを用いた 提案高周波ソフトスイッチング方式 TIG 溶接機用電源（低 電圧 5-32 V, 大電流 $300 \mathrm{~A}$ ）の実用化開発を行っており, そ の有効性を明らかにしている。

\section{2. 新方式溶接機用電源}

〈2・1〉回路構成図 1 に新方式電圧形フルブリッジ ソフトスイッチング PWM 高周波インバータを用いた高周 波トランス絶縁型 DC-DC コンバータ回路を示す。一般的 な電圧形単相フルブリッジインバータ左側ブリッジレッグ スイッチ $\mathrm{Q}_{1}\left(\mathrm{~S}_{1} / \mathrm{D}_{1}\right) / \mathrm{Q}_{2}\left(\mathrm{~S}_{2} / \mathrm{D}_{2}\right)$, 右側ブリッジレッグスイッ 于 $\mathrm{Q}_{3}\left(\mathrm{~S}_{3} / \mathrm{D}_{3}\right) / \mathrm{Q}_{4}\left(\mathrm{~S}_{4} / \mathrm{D}_{4}\right)$ の $\mathrm{DC}$ バスラインと直列に追加ス イッチ $\mathrm{Q}_{5}\left(\mathrm{~S}_{5} / \mathrm{D}_{5}\right)$ と $\mathrm{DC}$ バスライン間の追加一括ロスレス スナバコンデンサ C からなるアクティブ補助部分共振スナ バを付加した構成となっている。溶接機の低電圧・大電流 直流出力形式では, 高周波トランス 2 次巻線はセンタータッ プ構造をとり 2 つ高速整流ダイオード $\mathrm{D}_{6}, \mathrm{D}_{7}$ を持つ構成 である。溶接機用高周波センタータップトランス整流回路 の出力フィルタとして直流リアクトルを用いている。フル ブリッジインバータ部のスイッチング周波数を約 $10 \mathrm{kHz}$ $100 \mathrm{kHz}$ (本論文の試作実験回路では $60 \mathrm{kHz}$ として設計） とすることにより高周波トランスとフィルタ用直流リアク トルの小型軽量化を図っている。

電圧形フルブリッジインバータのスイッチ $\mathrm{Q}_{1}, \mathrm{Q}_{4}$ 及び $\mathrm{Q}_{2}, \mathrm{Q}_{3}$ がブリッジアーム内に対角的にそれぞれ接続され ている。 $\mathrm{Q}_{1}, \mathrm{Q}_{2}$ 及び $\mathrm{Q}_{3}, \mathrm{Q}_{4}$ には2 in1 の IGBT パワーモ ジュールを用いている。フルブリッジインバータ部の出力 側にはセンタータップ 2 次巻線付高周波トランス $\mathrm{T}$ と直列 インダクタ $\mathrm{L}_{1}$ が接続されている。なお直列インダクタ $\mathrm{L}_{1}$ は高周波トランスの漏れインダクタンスと等価的なインダ クタンスを利用する。センタータップ 2 次巻線付高周波卜 ランスの 2 次回路部は, ダイオード $\mathrm{D}_{6}, \mathrm{D}_{7}$ によるセンター タップ全波整流回路が用いられ，直流リアクトル (DCL) フィルタ $\mathrm{L}_{2}$ を通して負荷 $\mathrm{R}$ （TIG アーク溶接トーチ）が 接続されている。

本新方式高周波絶縁型ソフトスイッチング PWM DCDC コンバータ回路では, DC バスライン直列追加スイッチ $\mathrm{Q}_{5}\left(\mathrm{~S}_{5} / \mathrm{D}_{5}\right)$ が直流電源 $\mathrm{E}$ とフルブリッジインバータブリッ 


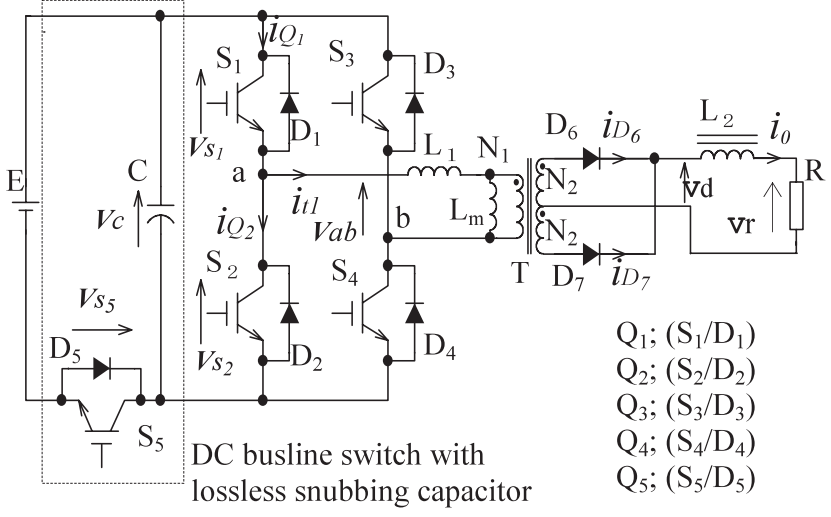

図 1 新方式電圧形フルブリッジソフトスイッチング PWM インバータを用いた DC-DC コンバータ回路

Fig. 1. Advanced high power DC-DC converter circuit using a novel type full-bridge soft-switching PWM inverter with high frequency transformer link.

ジレッグ間に直列挿入される。また DCバスラインと並列 に追加コンデンサ C が DC バスライン直列追加スイッチ $\mathrm{Q}_{5}\left(\mathrm{~S}_{5} / \mathrm{D}_{5}\right)$ とフルブリッジインバータ間に接続されている。

〈2·2〉本 DC-DC コンバータのスイッチ動作モード フルブリッジインバータのスイッチ $\left(\mathrm{Q}_{1}, \mathrm{Q}_{4}\right)$ 又は $\left(\mathrm{Q}_{2}, \mathrm{Q}_{3}\right)$ をそれぞれ同時にオフする時より少し前に DC バスライン 直列追加スイッチ $\mathrm{Q}_{5}$ をオフする。そこで一旦直流電源 $\mathrm{E}$ からフルブリッジインバータへの電力供給がカットオフさ れる。 $\mathrm{Q}_{5}$ の導通期間中に $\mathrm{E} に$ 充電された $\mathrm{DC}$ バスライン 並列追加ロスレススナバコンデンサ C の電荷が高周波卜 ランスの 1 次巻線ループを含む回路を通して放電し， C の 電圧がゼロになった後に，ブリッジ対角アーム内スイッチ $\left(\mathrm{Q}_{1}, \mathrm{Q}_{4}\right)$ 又はスイッチ $\left(\mathrm{Q}_{2}, \mathrm{Q}_{3}\right)$ をオフすることで，スイッ 于 $\mathrm{Q}_{1}, \mathrm{Q}_{4}$ 又はスイッチ $\mathrm{Q}_{2}, \mathrm{Q}_{3}$ のゼロ電圧ソフトスイッチ ング $(\mathrm{ZVS})$ ターンオフ動作が可能である。スイッチ $\mathrm{Q}_{1}$, $\mathrm{Q}_{4}$ 又はスイッチ $\mathrm{Q}_{2}, \mathrm{Q}_{3}$ のターンオン時，フルブリッジ高 周波インバータの出力高周波 $\mathrm{AC}$ 側の直列インダクタ $\mathrm{L}_{1}$ に より，ブリッジアーム内の各スイッチ電流はゼロからの立 ち上がりとなる。従って, ブリッジアーム内の各スイッチ は，ゼロ電流ソフトスイッチング $(\mathrm{ZCS})$ ターンオン動作 となる。

一方, $\mathrm{DC}$ バスライン直列追加スイッチ $\mathrm{Q}_{5}$ のターンオフ は, DC バスライン並列ロスレススナバコンデンサ $\mathrm{C}$ の効果 により ZVS ターンオフができる。 $\mathrm{Q}_{5}$ のターンオン時，フ ルブリッジアーム内のスイッチ $\mathrm{Q}_{1}, \mathrm{Q}_{4}$ 又はスイッチ $\mathrm{Q}_{2}$, $\mathrm{Q}_{3}$ のターンオフ後に部分共振用としてのインダクタ $\mathrm{L}_{1}$ に 蓄えられた電磁エネルギーが DC バスライン並列ロスレス スナバコンデンサ C に帰還されコンデンサ C は直流電源電 圧 $\mathrm{E}$ まで充電されるため， $\mathrm{Q}_{5}$ は Z VS でターンオン動作す る。その上, $\mathrm{Q}_{5}$ はインダクタ $\mathrm{L}_{1}$ の存在のため, $\mathrm{Q}_{1}, \mathrm{Q}_{4}$ 並 びに $\mathrm{Q}_{2}, \mathrm{Q}_{3}$ と同様 ZCS ターンオン動作となる。

\section{3. 回路動作}

$\langle 3 \cdot 1\rangle$ ゲートパルスタイミングシーケンス

図 2 に

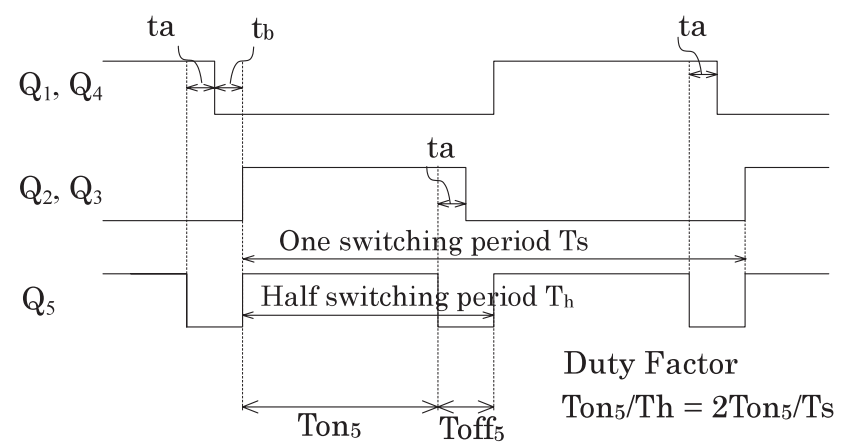

図 2 本 DC-DC コンバータのゲートパルスパターン タイミングシーケンス

Fig. 2. Pattern sequences of switching gate driving pulses for the switches.

本 DC-DC コンバータ（図 1 参照）の各スイッチのゲート 信号パターンの動作タイミングシーケンスを示す。ブリッ ジアーム内のスイッチ $\mathrm{Q}_{1}, \mathrm{Q}_{4}$ 並びにスイッチ $\mathrm{Q}_{2}, \mathrm{Q}_{3}$ は従 来のハードスイッチング PWM 制御高周波インバータと同 様デッドタイム $\mathrm{t}_{\mathrm{b}}$ をもって一定周期で交互にオン，オフ動 作を繰り返す。DCバスライン直列追加スイッチ $\mathrm{Q}_{5}$ は，ス イッチ $\mathrm{Q}_{1}, \mathrm{Q}_{4}$ 並びにスイッチ $\mathrm{Q}_{2}, \mathrm{Q}_{3}$ とそれぞれ同時にオ ンする。 $\mathrm{Q}_{5}$ のオフ時は, スイッチ $\mathrm{Q}_{1}, \mathrm{Q}_{4}$ 並びにスイッチ $\mathrm{Q}_{2}, \mathrm{Q}_{3}$ がオフする微少時間 $\mathrm{t}_{\mathrm{a}}$ 前にオフするようにゲート 信号が与えられる。言い換えれば，DCバスライン直列追加 スイッチ $\mathrm{Q}_{5}$ がオフしてから $\mathrm{t}_{\mathrm{a}}$ 後に，スイッチ $\mathrm{Q}_{1}, \mathrm{Q}_{4}$ 並び にスイッチ $\mathrm{Q}_{2}, \mathrm{Q}_{3}$ がターンオフするようにゲート信号が 与えられる。なお, 図 2 における $\mathrm{t}_{b}$ は, いわゆるブリッジ 高周波インバータ内のスイッチ $\mathrm{Q}_{1}, \mathrm{Q}_{2}$ 又は $\mathrm{Q}_{3}, \mathrm{Q}_{4}$ のデッ トタイムに相当する。従って, $\mathrm{Q}_{5}$ の導通パルス幅 $\mathrm{Ton}_{5}$ は, $(1 / 2) \mathrm{T}_{\mathrm{S}}-\left(\mathrm{t}_{\mathrm{a}}+\mathrm{t}_{\mathrm{b}}\right)$ の範囲でパルス幅変調されることとなる。 また，デユーティファクターは， $\mathrm{Ton}_{5} / \mathrm{Th}=2 \mathrm{Ton}_{5} / \mathrm{Ts}$ で求 められる。

〈3.2〉回路動作 図 3 にゲートパルスパターンタイ ミングに対する本 DC-DC コンバータ回路の各部動作波形 を示す。また本回路のスイッチング半周期 $\mathrm{T}_{\mathrm{h}}$ の動作パル スタイミング時点 $\left(\mathrm{t}_{0} \sim \mathrm{t}_{6}\right)$ で区分される Mode0 Mode6 のモード遷移に対する動作等価回路を図 4 に示す。以下本 DC-DC コンバータの動作等価回路と対応させながら前半 周期 $\mathrm{T}_{\mathrm{h}}$ 内の Mode $0 \sim$ Mode6 について順次説明する。

Mode0：～ $\mathrm{t}_{0}$ (パワー伝達モード） 時刻 $\mathrm{t}_{0}$ 以前の期間 においては，ブリッジインバータ対角アーム内のスイッチ $\mathrm{Q}_{1}, \mathrm{Q}_{4}$ と $\mathrm{DC}$ バスライン直列追加スイッチ $\mathrm{Q}_{5}$ にゲート信 号が印加されている。高周波トランス $\mathrm{T}$ の 1 次電流 $\mathrm{i}_{\mathrm{t}}$ が流 れている。 $\mathrm{Q}_{1}, \mathrm{Q}_{4}$ と $\mathrm{Q}_{5}$ にもそれぞれ $\mathrm{i}_{t 1}$ と同一 $\left(\mathrm{i}_{\mathrm{Q} 1}=\mathrm{i}_{\mathrm{Q} 5}\right)$ 電流が流れている。このとき $\mathrm{DC}$ バスライン並列コンデン サ C は, 直流電源電圧 $\mathrm{E}$ まで充電されていることになる。 高周波トランス $\mathrm{T}$ の 2 次側（センタータップ巻線）回路の ダイオード $\mathrm{D}_{6}$ が導通し， $\mathrm{D}_{6} \rightarrow$ 直流リアクトル $\mathrm{L}_{2} \rightarrow$ 負荷 $\mathrm{R} \rightarrow$ 高周波卜ランス 2 次巻線の経路で電流が流れる。

Mode1 $: \mathrm{t}_{0} \sim \mathrm{t}_{1}\left(\mathrm{Q}_{5}\right.$ ターンオフと $\mathrm{C}$ 放電モード $)$ 時 


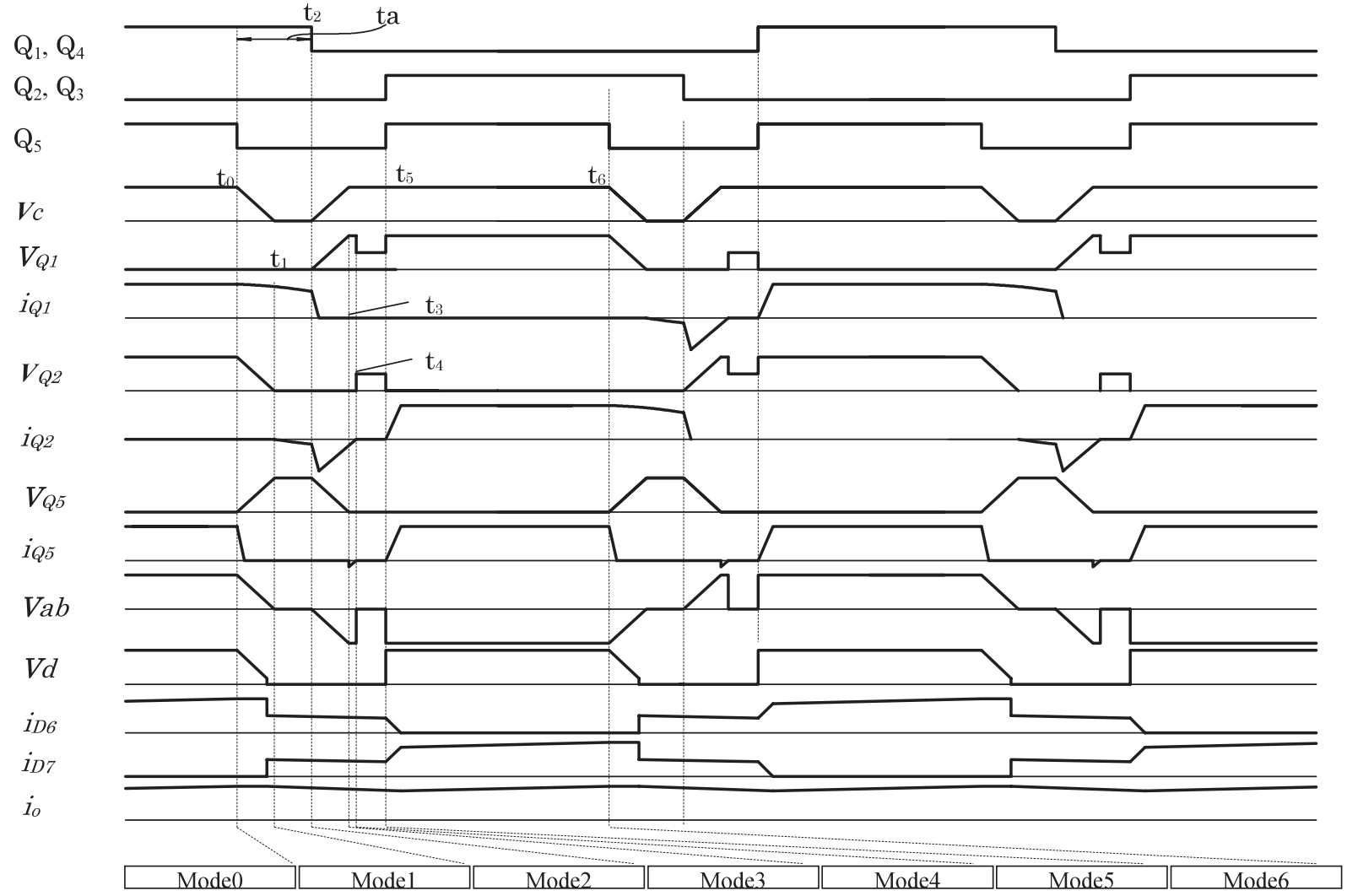

図 3 ゲートパーターン動作タイミングと定常動作波形

Fig. 3. Steady state operating waveforms under the pulse pattern of switching gate drive timing sequences.

(a) $\operatorname{Mode} 0\left(\sim \mathrm{t}_{0}\right)$; Energy transfer to transformer secondary side

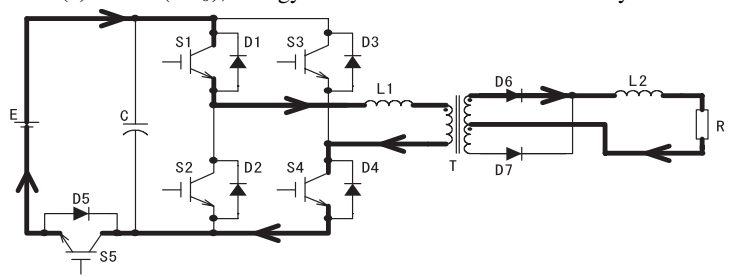

(b) Mode1 $\left(\mathrm{t}_{0} \sim \mathrm{t}_{1}\right)$; Discharge of $\mathrm{C}$ after $\mathrm{Q}_{5}$ is turned off

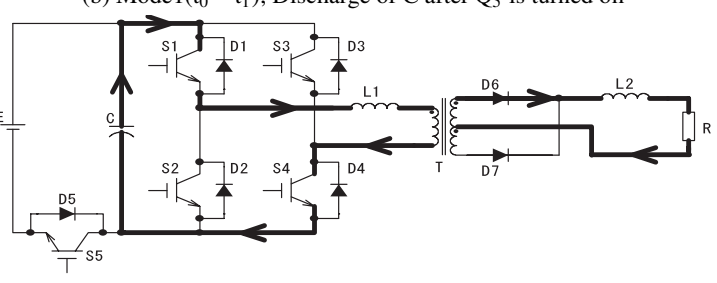

(c) Mode2 $\left(\mathrm{t}_{1} \sim \mathrm{t}_{2}\right)$; Current circulation after discharging of $\mathrm{C}$

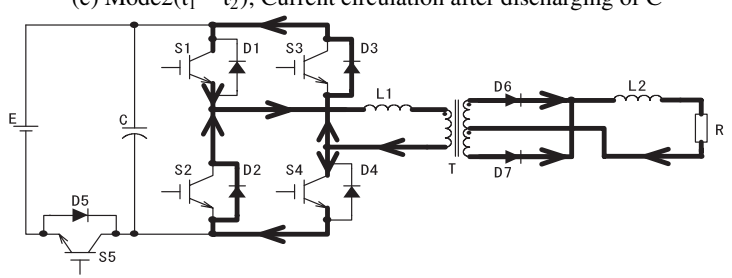

(d) Mode3 $\left(\mathrm{t}_{2} \sim \mathrm{t}_{3}\right)$; Charging of C after Q1, Q4 are turned off

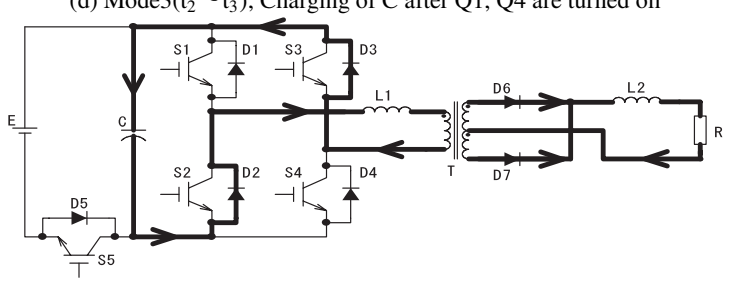

(e) Mode4 $\left(\mathrm{t}_{3} \sim \mathrm{t}_{4}\right) ; \boldsymbol{V}$ is clamped by $\mathrm{E}$

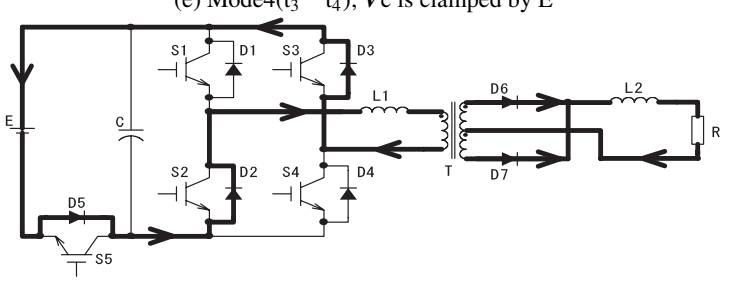

(f) Mode 5( $\left.t_{4} \sim t_{5}\right)$; No operation in transformer primary circuit

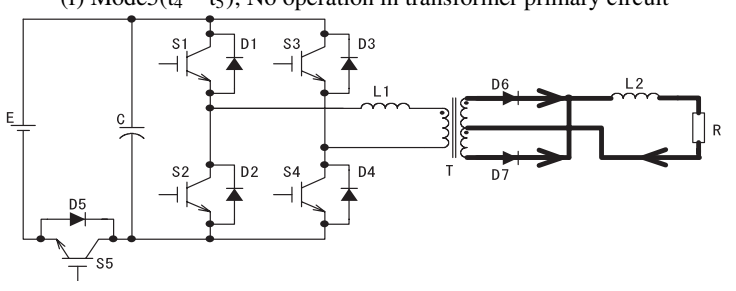

(g) Mode6 $\left(\mathrm{t}_{5} \sim \mathrm{t}_{6}\right)$; Energy transfer to transformer secondary side

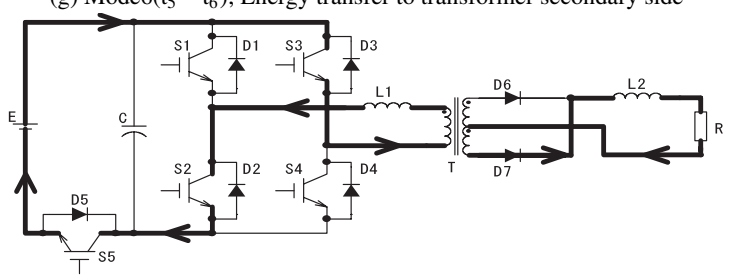

図 4 ゲートパルスタイミングシーケンスにおける 動作モード遷移と動作等価回路

Fig. 4. Equivalent circuits for the seven operational modes and mode transitions. 
刻 $\mathrm{t}_{0}$ の時点で, $\mathrm{DC}$ バスライン直列追加スイッチ $\mathrm{Q}_{5}$ に印加 されているゲート信号を除去し $\mathrm{Q}_{5}$ をターンオフする。高 周波トランスの 1 次電流 $\mathrm{i}_{\mathrm{t} 1}$ は直流電源電圧 $\mathrm{E}$ に充電され た DC バスライン並列コンデンサ $\mathrm{C}$ の放電電流となり， $\mathrm{Q}_{5}$ は ZVS で転流動作をする。C の電圧は高周波トランスの $\mathrm{L}_{1}$ と $\mathrm{C}$ の部分共振 1 次電流 $\mathrm{i}_{\mathrm{t} 1}$ によって放電していくこと となる。高周波トランスの 2 次側は, Mode0 同様に高速整 流ダイオード $\mathrm{D}_{6}$ の導通状態が続いている。高周波トラン ス $\mathrm{T}$ の 2 次電圧 $V_{d}$ が負荷 $\mathrm{R}$ の電圧以下になると直流フィ ルタリアクトル $\mathrm{L}_{2}$ がエネルギーを放出するフライホイー ルモードに入る。すなわち， $\mathrm{D}_{6}, \mathrm{D}_{7}$ が同時に導通状態と なる。

この動作モードに㧍ける DC バスライン並列ロスレスス ナバコンデンサ $\mathrm{C}$ の電圧は, 近似的に $\mathrm{i}_{\mathrm{t} 1}\left(\mathrm{t}_{0}\right)$ をほほ一定と すると，

$$
V \mathrm{c}(\mathrm{t})=\mathrm{E}-\left(\mathrm{i}_{\mathrm{t} 1}\left(\mathrm{t}_{0}\right) / \mathrm{C}\right) \mathrm{t} \cdot
$$

(1) 式に従ってCの電圧が放電を始めてこれがゼロになる までの時間 txは，(1) 式より (2) 式として与えられる。

$$
\mathrm{tx}=\mathrm{E} \cdot \mathrm{C} / \mathrm{i}_{\mathrm{t} 1}\left(\mathrm{t}_{0}\right) \cdot
$$

(2) 式より，高周波トランスの 1 次電流 $\mathrm{i}_{\mathrm{t} 1}\left(\mathrm{t}_{0}\right)$ つまり $\mathrm{L}_{1}$ の 電流が大きいほど DC バスライン並列ロスレススナバコン デンサ C の放電時間 $\mathrm{tx}$ は実質上短いことがわかる。逆に, $\mathrm{i}_{\mathrm{t} 1}\left(\mathrm{t}_{0}\right)$ が小さければ長くなることは言うまでもない。本 DCDC コンバータでは， DC バスライン直列追加スイッチ $\mathrm{Q}_{5}$ がターンオフしてから, 対角的ブリッジアーム内のスイッ チ $\mathrm{Q}_{1}, \mathrm{Q}_{4}$ 並びに $\mathrm{Q}_{2}, \mathrm{Q}_{3}$ がターンオフするまでの時間で ある $\mathrm{t}_{\mathrm{a}}$ は高周波トランスの 1 次電流 $\mathrm{i}_{\mathrm{t} 1}\left(\mathrm{t}_{0}\right)$ の最大条件をも とに，上式に示される時間 $\mathrm{tx}$ 以上に設定される。従って, この場合，最大負荷電流で決まる重負荷領域ではスイッチ $\mathrm{Q}_{1}, \mathrm{Q}_{4}$ 並びに $\mathrm{Q}_{2} ， \mathrm{Q}_{3}$ は完全な ZVS でターンオフしてい る。この ZVS ターンオフ領域を広げる場合は, $\mathrm{i}_{\mathrm{t} 1}\left(\mathrm{t}_{0}\right)$ の電 流值に応じて $\mathrm{t}_{\mathrm{a}}$ を変化させる工夫が必要である。高周波卜 ランスの励磁インダクタンスが小さい時にはこの限りでは ない。

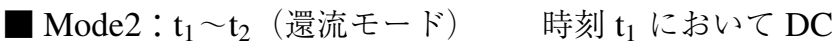
バスライン並列ロスレススナバコンデンサ C の電圧はゼロ となる。時刻 $\mathrm{t}_{1} \sim$ 時刻 $\mathrm{t}_{2}$ の期間は, $\mathrm{Q}_{2}$ の $\mathrm{D}_{2}, \mathrm{Q}_{3}$ の $\mathrm{D}_{3}$ が それぞれオンしている。高周波トランスの 1 次電流 $\mathrm{i}_{\mathrm{t}}$ の 還流電流は, $\mathrm{D}_{3}\left(\mathrm{Q}_{3}\right) \rightarrow \mathrm{S}_{1}\left(\mathrm{Q}_{1}\right) \rightarrow \mathrm{T}$ と $\mathrm{S}_{4}\left(\mathrm{Q}_{4}\right) \rightarrow \mathrm{D}_{2}\left(\mathrm{Q}_{2}\right) \rightarrow \mathrm{T}$ の 2 つの経路に分流する。高周波トランスの 2 次側は, 高速 整流ダイオード $\mathrm{D}_{6}, \mathrm{D}_{7}$ が同時に導通するフライホイール モードが継続している。

Mode $3: t_{2} \sim t_{3}\left(Q_{1}, Q_{4}\right.$ ターンオフと $\mathrm{C}$ 充電モード $)$ 時刻 $\mathrm{t}_{2}$ に扔いてブリッジ対角アーム内のスイッチ $\mathrm{Q}_{1}, \mathrm{Q}_{4}$ に印加されていたゲート信号を除去することにより， $\mathrm{Q}_{1}$, $\mathrm{Q}_{4}$ をターンオフする。このとき， DCバスライン並列ロス レススナバコンデンサ C の電圧は既にゼロとなっており， $\mathrm{Q}_{2}$ の $\mathrm{D}_{2}, \mathrm{Q}_{3}$ の $\mathrm{D}_{3}$ が直ちに自然ターンオンする。そこで,
ブリッジ対角アームスイッチ $\mathrm{Q}_{1}, \mathrm{Q}_{4}$ は ZVS できる。その 後, 高周波トランスの直列インダクタ $\mathrm{L}_{1}$ に蓄えられた電磁 エネルギーで DC バスライン並列ロスレススナバコンデン サ C が直流電源電圧 $\mathrm{E}$ まで充電される。高周波卜ランス 2 次側は, 高速整流ダイオード $\mathrm{D}_{6}, \mathrm{D}_{7}$ が同時に導通してい るフライホイールモードが継続している。

このとき, DC バスライン並列ロスレススナバコンデン サ Cが直流電源電圧 $\mathrm{E}$ まで充電される条件は (3) 式で求め られる。すなわち，

$$
(1 / 2) \mathrm{CE}^{2}=(1 / 2) \mathrm{L}_{1}\left(\mathrm{i}_{\mathrm{t} 1}\left(\mathrm{t}_{0}\right)\right)^{2} .
$$

しかし，通常は後述する Mode6 での DC バスライン直 列追加スイッチ $\mathrm{Q}_{5}$ がターンオンする時の ZVS 転流を実現 するために, $(1 / 2) \mathrm{CE}^{2} \leqq(1 / 2) \mathrm{L}_{1}\left(\mathrm{i}_{\mathrm{t} 1}\left(\mathrm{t}_{0}\right)\right)^{2}$ となるように回路 定数 $\mathrm{C}, \mathrm{L}_{1}$ （高周波トランスの漏れインダクタンスで決定） が決定されなければならない。

D Mode $4: \mathrm{t}_{3} \sim \mathrm{t}_{4}\left(\mathrm{~L}_{1}\right.$ の電磁エネルギーの直流電源電圧へ の帰還モード） $(1 / 2) \mathrm{CE}^{2}<(1 / 2) \mathrm{L}_{1}\left(\mathrm{i}_{\mathrm{t} 1}\left(\mathrm{t}_{0}\right)\right)^{2}$ を満たす回 路定数 $\mathrm{C}$ が使用されている場合は, $\mathrm{DC}$ バスライン並列口 スレススナバコンデンサ $\mathrm{C}$ の電圧が直流電源電圧 $\mathrm{E}$ 以上に なると $\mathrm{Q}_{5}$ の $\mathrm{D}_{5}$ がターンオンして， $\mathrm{L}_{1}$ に蓄えられた電磁 エネルギーは直流電源側 $\mathrm{E}$ に戻る。 $\mathrm{DC}$ バスライン並列ロ スレススナバコンデンサ $\mathrm{C}$ の電圧は直流電源電圧 $\mathrm{E}$ にク ランプされる。高周波トランス 2 次側は, 高速ダイオード $\mathrm{D}_{6}, \mathrm{D}_{7}$ が同時に導通するフライホイールモードが更に継 続する。

- Mode 5: $\mathrm{t}_{4} \sim \mathrm{t}_{5}$ （高周波トランス 1 次回路の動作停止 モード）フルブリッジ高周波インバータ部の回路動作 が停止している状態である。時刻 $\mathrm{t}_{4}$ でスイッチ $\mathrm{Q}_{1}, \mathrm{Q}_{4}$ に 印加されていた直流電源電圧 $\mathrm{E}$ が，ブリッジアーム内の全 てのスイッチ IGBTs $; \mathrm{Q}_{1}, \mathrm{Q}_{2}, \mathrm{Q}_{3}, \mathrm{Q}_{4}$ のオフ時コレクター エミッ夕間の寄生容量によりバランスし, 約 $1 / 2 \mathrm{E}$ の電圧が $\mathrm{Q}_{1}, \mathrm{Q}_{2}, \mathrm{Q}_{3}, \mathrm{Q}_{4}$ の各スイッチに印加される動作状態とな る。高周波トランス 2 次側は, 高速整流ダイオード $\mathrm{D}_{6}, \mathrm{D}_{7}$ が同時に導通するフライホイールモードがいまな㧍継続し ている。

ロ Mode6 : $\mathrm{t}_{5} \sim \mathrm{t}_{6}$ (パワー伝達モード）＼cjkstart時刻 $\mathrm{t}_{5}$ にて ブリッジ対角アームスイッチ $\mathrm{Q}_{2}, \mathrm{Q}_{3}$ 及びスイッチ $\mathrm{Q}_{5}$ が同 時にオンとなる。フルブリッジ高周波インバータの出力側 には直列インダクタ $\mathrm{L}_{1}$ が存在するため, $\mathrm{Q}_{2}, \mathrm{Q}_{3}$ は ZCS で きる。また, $\mathrm{Q}_{5}$ に関しては， $\mathrm{Q}_{2}, \mathrm{Q}_{3}$ と同様に直列インダ クタ $\mathrm{L}_{1}$ の存在と, $\mathrm{DC}$ バスライン並列ロスレススナバコン デンサ C が直流電源電圧 $\mathrm{E}$ に充電されているために ZVS かつ ZCS の混合でターンオンする。高周波トランス 2 次 側は, 高速整流ダイオード $\mathrm{D}_{7}$ のみの単流導通状態に代わ り, 高周波トランスの 1 次側の電磁エネルギーが, $\mathrm{D}_{7} \rightarrow$ 直流リアクトル $\mathrm{L}_{2} \rightarrow$ 負荷 $\mathrm{R} \rightarrow$ 高周波トランス 2 次巻線の 経路で負荷 $\mathrm{R}$ に供給される。

これ以降の回路動作 (Mode7〜Mode12) は，ブリッジ対 角アームスイッチ $\mathrm{Q}_{1}, \mathrm{Q}_{4}$ が $\mathrm{Q}_{2}, \mathrm{Q}_{3}$ に置き換わるだけで, 


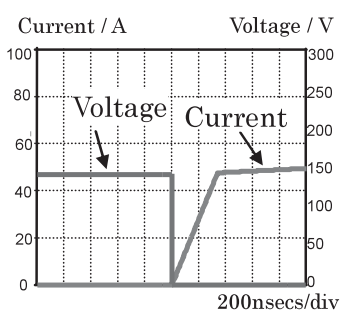

(a) Turn-on switching waveforms for $\mathrm{Q}_{1} \sim \mathrm{Q}_{4}$

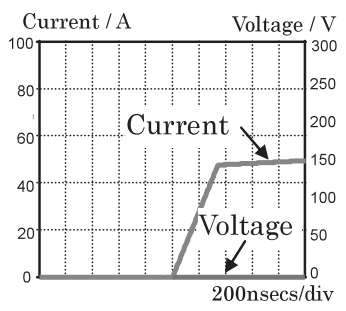

(c) Turn-on switching waveforms for $\mathrm{Q}_{5}$

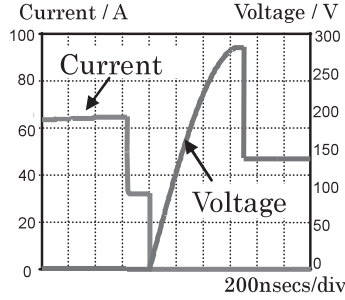

(b) Turn-off switching waveforms for $\mathrm{Q}_{1} \sim \mathrm{Q}_{4}$

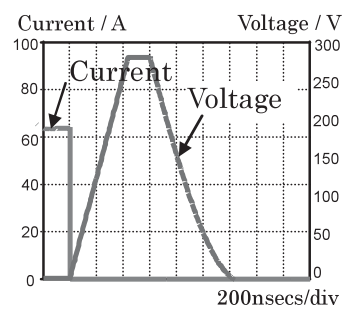

(d) Turn-off switching waveforms for $\mathrm{Q}_{5}$
図 $5 \mathrm{Q}_{1} \sim \mathrm{Q}_{4}$ と $\mathrm{Q}_{5}$ のシミュレーション電圧と 電流波形

Fig. 5. Simulated switching voltage and current waveforms for the switches $\mathrm{Q}_{1} \sim \mathrm{Q}_{4}$ and $\mathrm{Q}_{5}$.

表 1 シミュレーションの設計仕様と回路定数

Table 1. Design specification and circuit parameters for simulation

\begin{tabular}{l|c|c}
\hline $\begin{array}{l}\text { Leakage Inductance of High } \\
\text { Frequency Transformer }\end{array}$ & $\mathrm{L}_{1}$ & $2[\mu \mathrm{H}]$ \\
\hline $\begin{array}{l}\text { Capacitance of Quasi } \\
\text { Resonant Condenser }\end{array}$ & $\mathrm{C}$ & $0.1[\mu \mathrm{F}]$ \\
\hline DC Reactor in Load Side & $\mathrm{L}_{2}$ & $100[\mu \mathrm{H}]$ \\
\hline Load Resistance & $\mathrm{R}$ & $0.07[\Omega]$ \\
\hline $\begin{array}{l}\text { Average Maximum Load } \\
\text { Current }\end{array}$ & $\mathrm{Io}$ & $300[\mathrm{~A}]$ \\
\hline $\begin{array}{l}\text { Turns Ratio of High } \\
\text { Frequency Transformer T }\end{array}$ & $\mathrm{N}_{1}: \mathrm{N}_{2}: \mathrm{N}_{2}$ & $5: 1: 1$ \\
\hline
\end{tabular}

Mode1 Mode6 と同様の動作となる。

〈3·3〉 シミュレーション波形図 5(a), (b) にスイッ チ $\mathrm{Q}_{1} \sim \mathrm{Q}_{4}$ のターンオン時・ターンオフ時の電圧と電流の シミュレーション波形を示す。図 5(c), (d) にスイッチ $\mathrm{Q}_{5}$ のターンオン時，ターンオフ時の電圧と電流のシミュレー ション波形を示す。本 DC-DC コンバータ（図 1 参照）の シミュレーションは，表 1 に示す設計仕様と各回路定数で 行っている。

図 5 に示すシミュレーション波形より，スイッチ $\mathrm{Q}_{1}$ 〜 $\mathrm{Q}_{4}$ は ZCS でターンオンし, ZVS でターンオフしている ことが分かる。また， DC バスライン直列追加スイッチ $\mathrm{Q}_{5}$ はZZVSZZCSの理想的なソフトスイッチング転流モードで ターンオンし, しかも, ZVS でターンオフしているのが分 かる。

\section{4. 試作実験結果と評価検討}

$\langle\mathbf{4} \cdot 1\rangle$ 試作実験機 図 6 に新方式高周波絶縁型ソフト

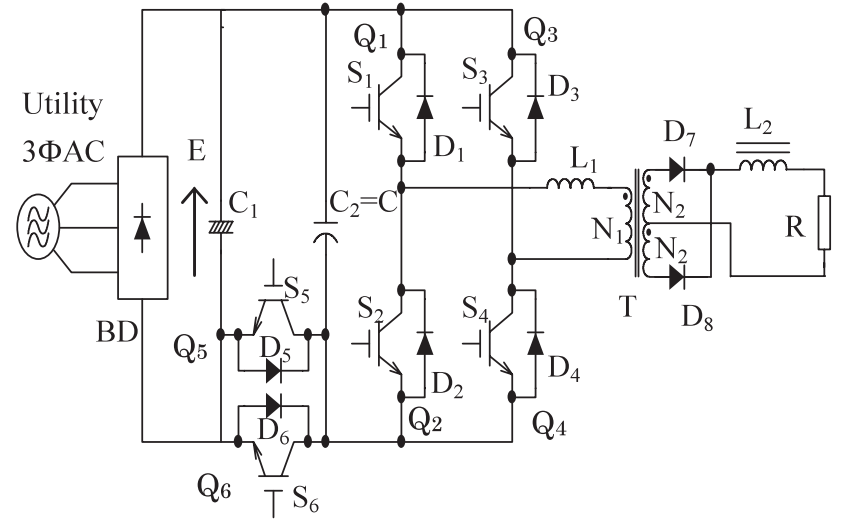

図 6 新方式ソフトスイッチング PWM 高周波 絶縁型 DC-DC コンバータの実験回路

Fig. 6. Experimental setup for newly-developed soft-switching PWM DC-DC converter with a high frequency transformer link and center- tapped high frequency rectifier.

表 2 設計仕様と回路定数

Table 2. Design specification and circuit parameters.

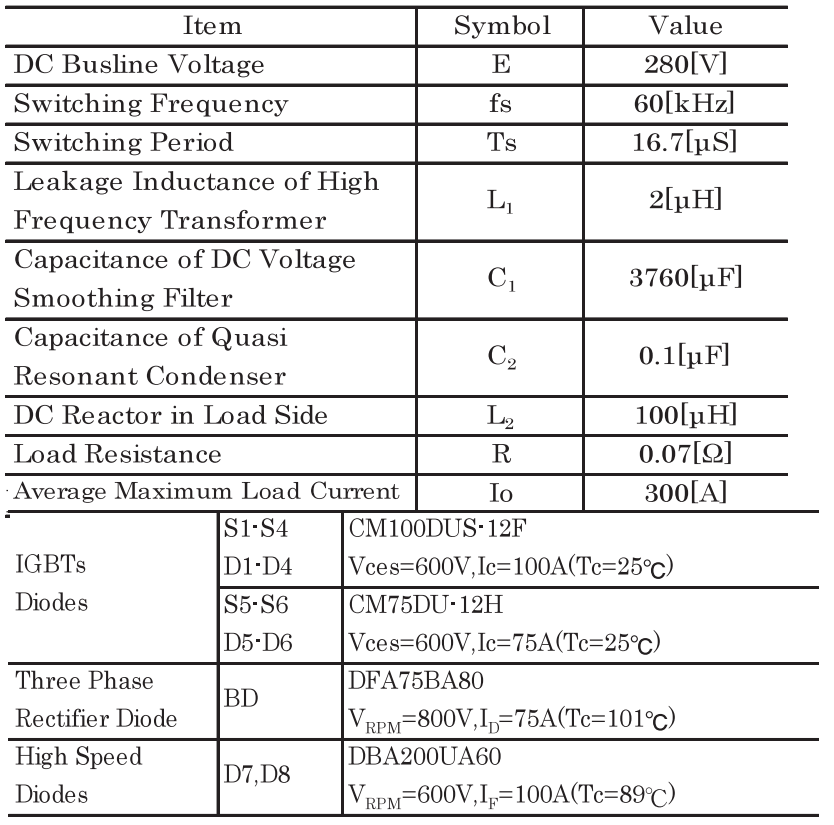

スイッチング PWM DC-DC コンバータの試作実験回路を示 す。主回路は, 直流電源 $\mathrm{E}$ は三相ブリッジ整流コンバータ の平滑フィルタコンデンサ出力として得られる。表 2 に本 DC-DC コンバータの設計仕様と回路定数を示す。スイッ チ $\mathrm{Q}_{1}, \mathrm{Q}_{2}$ とスイッチ $\mathrm{Q}_{3}, \mathrm{Q}_{4}$ は $2 \mathrm{in} 1$ シリーズパス IGBT パワーモジュール（三菱電機社製 CM100DUS-12F）を使 用している。また, $\mathrm{DC}$ バスライン直列追加スイッチ $\mathrm{Q}_{5}$ と スイッチ $\mathrm{Q}_{6}$ には $2 \mathrm{in} 1$ シリーズパス IGBT パワーモジュー ル（三菱電機社製 CM75DU-12H；2 個の内 1 個未使用）を 使用している。DCバスライン直列追加スイッチとしては, 困 1 の $\mathrm{Q}_{5}$ のみでよいが，スイッチング周期を同一にする ため $\mathrm{Q}_{5}, \mathrm{Q}_{6}$ の並列接続をとり入れブリッジアームスイッ 


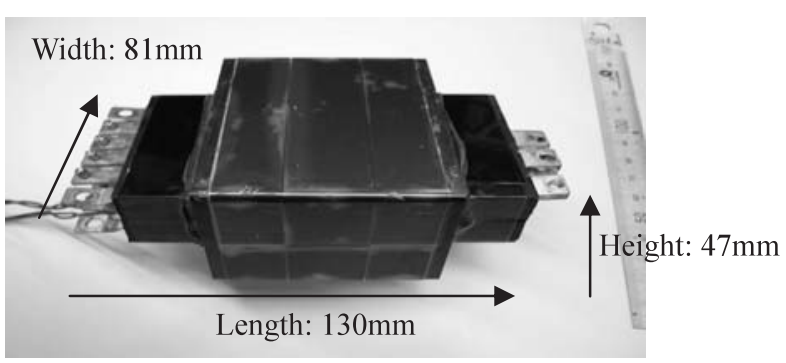

図 7 フラット高周波トランスの外観

Fig. 7. Exterior appearance for flat high frequency transformer with center-tapped secondary winding.

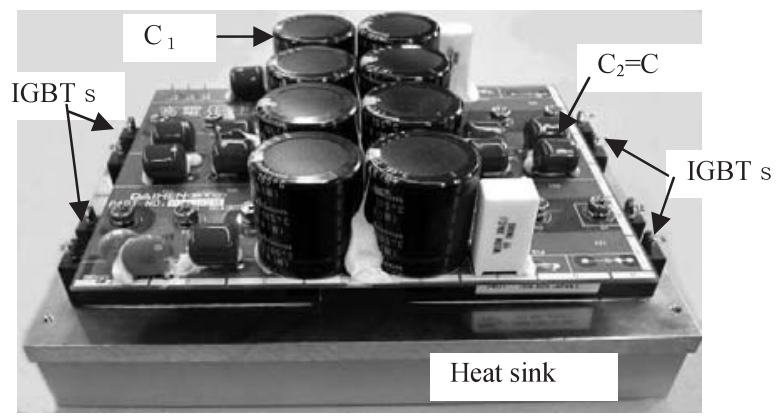

図 8 新方式ソフトスイッチング PWM DC-DC コンバータの高周波トランスの 1 次側主回路部品 のアセンブリボード外観

Fig. 8. Appearance for assembled circuit board in high frequency transformer primary side circuit of newlydeveloped soft-switching PWM DC-DC power converter with high frequency link.

チと同一時比率となるように時分割動作をさせている。

図 7 に, 図 6 の実験回路に使用されている高周波フラッ トトランス $\mathrm{T}$ の外観写真を示す。この高周波トランスの巻 線は，この高周波トランス専用に製作された金型で 1 ター ン状に打ち抜かれた銅板を積み重ね，銅板間をリベットで フラットに接続された構造であるため，高周波トランスの 高さが非常に低くなっている。

図 8 に,フルブリッジソフトスイッチング高周波絶縁型イ ンバータ部のアセンブリ外観を示す。4つの IGBT スイッ チ $\left(\mathrm{Q}_{1}, \mathrm{Q}_{2}\right),\left(\mathrm{Q}_{3}, \mathrm{Q}_{4}\right), \mathrm{DC}$ バスライン直列追加スイッチ $\mathrm{Q}_{5}$ と $\mathrm{Q}_{6}$ は，冷却用のヒートシンクに取り付けられており，プ リント基板で接続されている。プリント基板の表面には, コンデンサ $\mathrm{C}_{1}$ 及び $\mathrm{C}_{2}=\mathrm{C}$ が実装されており, 各 IGBT ス イッチ間や各 IGBT と DC バスライン間の配装ストレイイ ンダクタンスが最小限に抑えられている。この実装技術は, 本高周波絶縁型ソフトスイッチング DC-DC コンバータ回 路内の全スイッチのソフトスイッチング転流実現において 極めて重要となっている。

〈4・2〉 スイッチング動作波形の検証図 9(a)(b)に， スイッチ $\mathrm{Q}_{1}$ のターンオン時, ターンオフ時における電圧と 電流の実測波形をそれぞれ示す。 $\mathrm{Q}_{1}$ は ZCS でターンオン し, ZVS でターンオフしているのが図 9(a)(b) から分かる。 図 9(c)(d) に, DC バスライン直列追加スイッチ $\mathrm{Q}_{5}$ のター

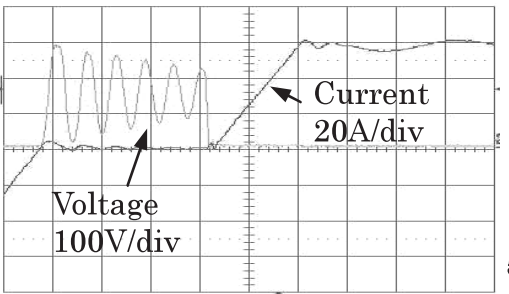

(a)

Turn-on switching waveforms for $\mathrm{Q}_{1}$

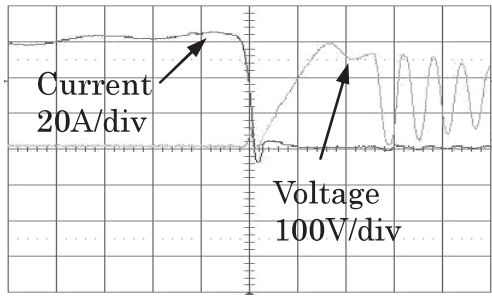

$500 \mathrm{~ns} / \mathrm{div}$

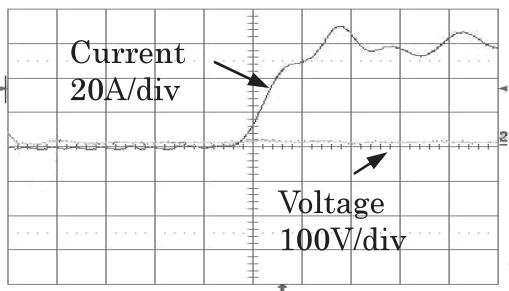

(b)

Turn-off switching waveforms for $Q_{1}$

$500 \mathrm{~ns} / \mathrm{div}$

(c)

Turn-on switching waveforms for $Q_{5}$

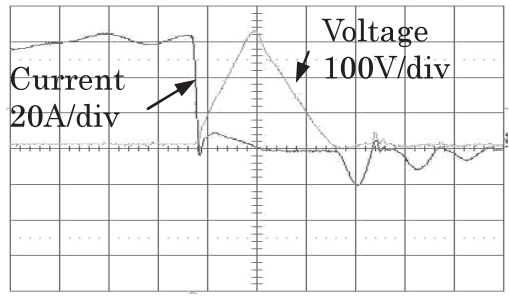

$500 \mathrm{~ns} / \mathrm{div}$

(d) Turn-off switching waveforms for $Q_{5}$

図 9 スイッチ $\mathrm{Q}_{1}, \mathrm{Q}_{5}$ のスイッチング波形

Fig. 9. Switching waveforms for the switches; $\mathrm{Q}_{1}, \mathrm{Q}_{5}$.

ンオン時, ターンオフ時における電圧と電流の実測波形を それぞれ示す。 $Q_{5}$ は ZVS と ZCS の混合転流でターンオ ンし, ZVS でターンオフしていることが図 9(c)(d) から分 かる。これらの波形は, 図 3 の $V_{Q 1}, i_{Q 1}$ と $V_{Q 5}, i_{Q 5}$ と対 応している。しかし, $\mathrm{Q}_{1}, \mathrm{Q}_{5}$ のターンオフ時には, IGBT 特有のテール電流特性の影響により, ソフトスイッチング 転流時でも若干のターンオフ損失が存在していることはや むを得ない。

〈4·3〉 スイッチ部損失比較 図 10 は, 同一出力電力 条件下で, 従来のハードスイッチング方式と本提案方式の ソフトスイッチング方式での損失を，スイッチング周波数 を変化させた条件下で比較したものである。図 10 の (a) は 本提案方式のソフトスイッチング PWM ブリッジ高周波イ ンバータの DC バスライン直列追加スイッチ $\mathrm{Q}_{5}, \mathrm{Q}_{6}$ を含む ブリッジ高周波インバータの全スイッチ損失の実測值（ス イッチング損失と導通損失), (b) は図 6 ·表 2 で構成される 試作実験機において DC バスライン直列追加スイッチ $\mathrm{Q}_{5}$, $\mathrm{Q}_{6}$ 及び DC バスライン並列ロスレススナバコンデンサを 取り除きハードスイッチング PWM で動作させた時のイン バータスイッチ部の損失, (c) は従来溶接機の PWM ブリッ ジ高周波インバータ部のスナバ回路損失を含む全スイッチ 


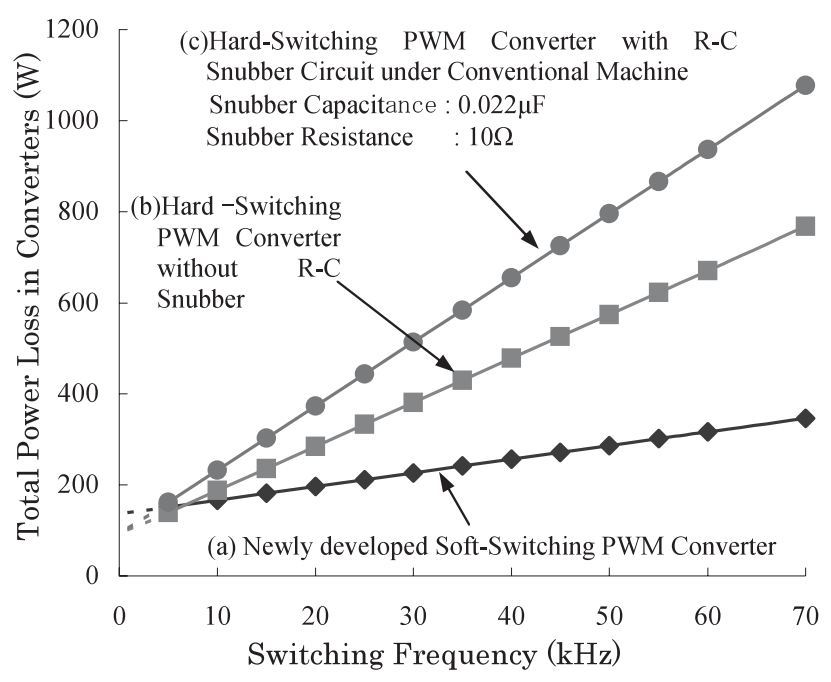

図 10 従来方式ハードスイッチング回路と新方式 ソフトスイッチング回路のスイッチ部損失比較

Fig. 10. Comparative power loss analysis between newly-developed soft-switching PWM and conventional hard-switching PWM DC-DC power converters.

損失の実測值（スイッチング損失／導通損失）をそれぞれ 示す。スイッチング周波数が約 $10 \mathrm{kHz}$ で従来方式と提案方 式の両者のスイッチ部全損失が等しくなり，それ以上の高 いスイッチング周波数帯になればなるほど，ソフトスイッ チング効果のため新方式高周波絶縁型 DC-DC コンバータ 回路が総合効率の面で有利となるといえる。

例えばフルブリッジ高周波インバータのスイッチング周 波数が $60 \mathrm{kHz}$ では図 10 の (a) で示す新方式ソフトスイッ チング PWM DC-DC コンバータ回路の全スイッチの損失 は $280 \mathrm{~W}$ と算出される。図 10 の (b) で示す同じ試作実験回 路でのハードスイッチング方式 DC-DC コンバータの全ス イッチの損失 (スイッチング損失・導通損失) は $670 \mathrm{~W}$ とな る。60kHzソフトスイッチング PWM DC-DC コンバータ のスイッチの損失（スイッチング損失・導通損失）はハード スイッチング PWM DC-DC コンバータのそれの約 42\%程 度になっており，極めて新提案ソフトスイッチング転流回 路方式 DC-DC コンバータの効果が高いといえる。

更に, 従来機のハードスイッチング PWM DC-DC コン バータでは, 各スイッチに対して最も簡素な RC スナバ回路 の損失を加えると全トータル損失が $900 \mathrm{~W}$ を超える。新方 式ソフトスイッチング PWM DC-DC コンバータを $60 \mathrm{kHz}$ のスイッチング周波数で動作させる場合，その全損失は従 来機のハードスイッチング PWM DC-DC コンバータに比 べ損失が $620 \mathrm{~W}$ 低減されていることになる。

\section{5. アーク溶接用電源への適用}

$\langle\mathbf{5} \cdot \mathbf{1}\rangle$ TIG 溶接の概要 TIG (Tungsten Inert Gas) 溶 接の原理及び TIG 溶接のアーク直流電圧一直流電流特性を 図 11 と図 12 にそれぞれ示す。不活性ガス（アルゴンやへ リウム）の雲囲気中で，タングステン電極と被溶接物の間

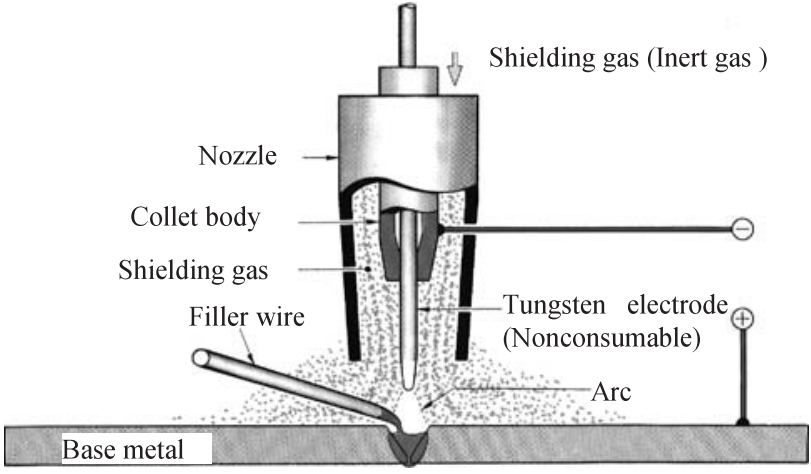

図 11 TIG 溶接の原理 ${ }^{(13)}$

Fig. 11. Principle of TIG welding ${ }^{(13)}$.

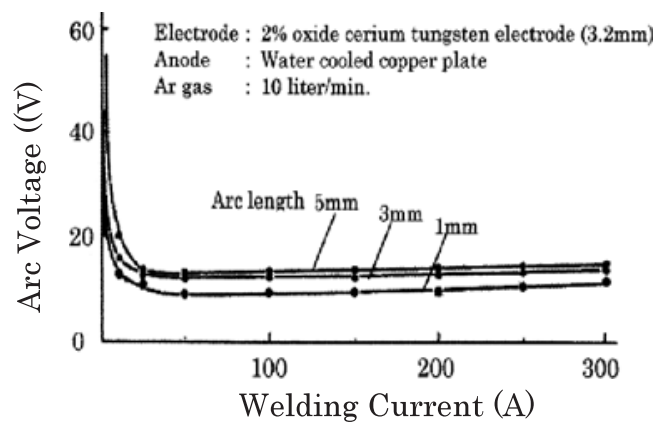

図 12 TIG 溶接のアーク電圧・電流特性 ${ }^{(14)}$

Fig. 12. Arc voltage-current characteristics for TIG welding under arc length conditions ${ }^{(14)}$.

でアーク放電を発生させ，そのアーク熱で金属を溶融させ 溶接を行う溶接法である。タングステン電極は非消耗電極 であり, 溶接部への肉盛りが必要な場合は, フィラワイヤ (添加棒) が挿入され溶接される。

図 12 のアーク特性からわかるように，アーク電流（溶 接電流）が約 $30 \mathrm{~A} \sim 40 \mathrm{~A}$ 以下の領域では, アーク電流が増 加するとアーク電圧が低下する負性抵抗特性を示す。一方 アーク電流 $30 \mathrm{~A} \sim 40 \mathrm{~A}$ での定電圧特性領域を経た後, アー ク電流が増加するほどアーク電圧も増加する正抵抗特性を 示す。TIG 溶接のアーク負荷は，小電流範囲での負性特性 があるものの，一般的には抵抗負荷として近似される。TIG 溶接電源用高周波絶縁型 DC-DC コンバー夕を議論すると きアーク負荷は抵抗 $\mathrm{R}$ として取扱ってもよい。また，TIG 溶接機では，アーク特性を安定に維持させるために，アー ク電流を一定に制御する定電流フィードバック制御が使わ れる。

〈5·2〉 新世代ソフトスイッチング PWM 高周波インバー 夕方式 TIG 溶接機図 13 は図 6 に示す本新方式高周波 絶縁型ソフトスイッチング PWM DC-DC コンバータを用い た最大出力 $300 \mathrm{~A}$ の TIG 溶接機の外観を示す。また, 図 14 に TIG 溶接機用の新方式高周波絶縁型ソフトスイッチング PWM DC-DC コンバータ電源システムのブロック図を示 す。図 14 に扔いて, 三相の商用電源の代わりに，バッテ リーやエンジン発電機が使用されることもある。将来は燃 


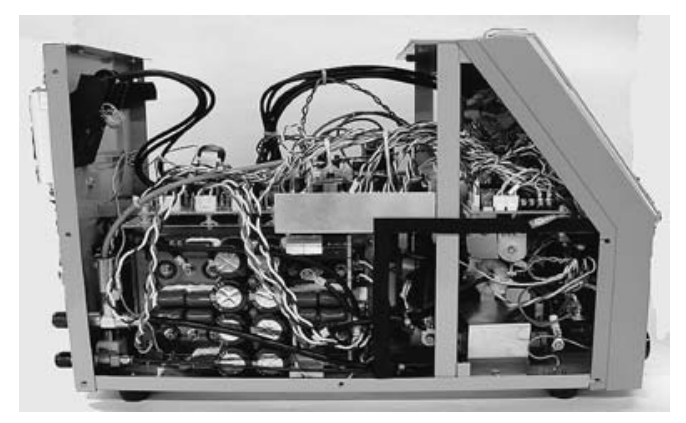

図 13 新方式ソフトスイッチング PWM 高周波 絶縁型 DC-DC コンバータを利用した TIG 溶接機 Fig. 13. Schematic whole appearance of TIG arc welding power supply equipment using newly-developed softswitching PWM DC-DC power converter with a high frequency transformer.

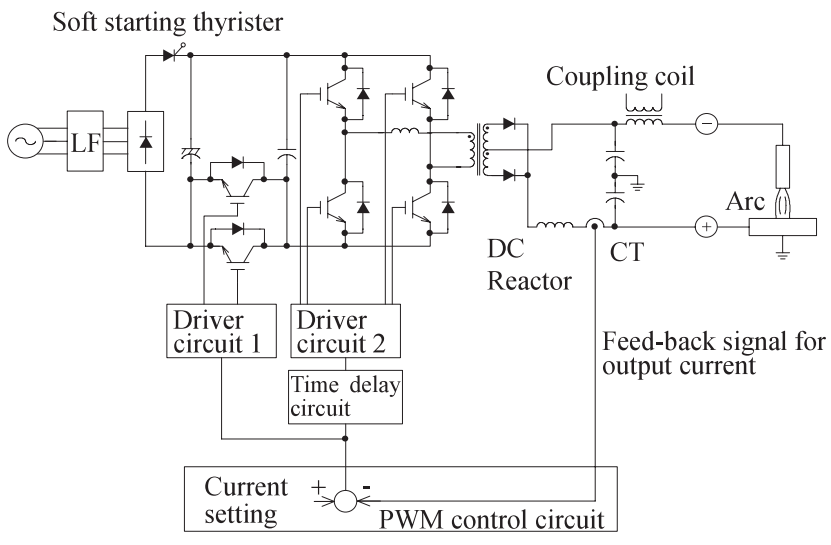

図 14 TIG 溶接機用の新提案方式スイッチング 電源システムのブロック図

Fig. 14. Block diagram for TIG welding power supply system using proposed soft-switching DC-DC converter.

料電池やスーパーキャパシタの導入も期待される。TIG 溶 接機は出力電流一定制御の特性が必要なため出力電流を CT （ホール電流検出器：HA400S3EH）やシャント抵抗で検出 して負帰還をかけて PWM 信号を生成し，パワーデバイス ドライブ回路を経由してフルブリッジ高周波ソフトスイッ チング $\mathrm{PWM}$ インバータ内のスイッチ $\mathrm{Q}_{1} \sim \mathrm{Q}_{4}$ 及び $\mathrm{DC}$ バ スライン直列追加スイッチ $\mathrm{Q}_{5}, \mathrm{Q}_{6}$ をそれぞれ駆動してい る。PWM 制御回路はスイッチングレギュレータ用 PWM 制御 IC（ $\mu$ PC494）を使用し, PWM 制御回路の出力信号 が DC バスライン直列追加スイッチ $\mathrm{Q}_{5}, \mathrm{Q}_{6}$ のゲート駆動 回路 1 に直接与えられる。電圧給電フルブルッジ高周波ソ フトスイッチング PWM インバータのブリッジアーム内ス イッチ $\mathrm{Q}_{1} \sim \mathrm{Q}_{4}$ のゲート駆動回路 2 には, DC バスライン 直列追加スイッチ $\mathrm{Q}_{5}, \mathrm{Q}_{6}$ のオフからスイッチ $\mathrm{Q}_{1}, \mathrm{Q}_{4}$ 又は $\mathrm{Q}_{2}, \mathrm{Q}_{3}$ のオフを遅延時間 ta（図 2 参照）だけ遅らせる信 号を生成するための遅延回路を通して与えられている。結 合コイル (Coupling coil) は，アークスタート時に周波数 $2 \mathrm{MHz}$ で電圧約 $5 \mathrm{kV}$ の高周波高電圧を電極一被溶接物間に 瞬時印加し，アーク電極を被溶接物に短絡接触させること
なくアークを起動させるために用いられているものである。

この TIG アーク溶接機は $300 \mathrm{~A}, 32 \mathrm{~V}$ から $4 \mathrm{~A}, 5 \mathrm{~V}$ まで の広範囲な直流出力を高速制御する必要がある。 DC バス ライン直列追加スイッチ $\mathrm{Q}_{5}, \mathrm{Q}_{6}$ のオフからスイッチ $\mathrm{Q}_{1}$, $\mathrm{Q}_{4}$ 又は $\mathrm{Q}_{2}, \mathrm{Q}_{3}$ のオフまでの遅れ時間 ta が固定の場合は, ブリッジアーム内スイッチ $\mathrm{Q}_{1} \sim \mathrm{Q}_{4}$ の最小パルス幅が ta と なり,アーク電流が数 $\mathrm{A}$ から数十 $\mathrm{A}$ 程度の低電流で安定 なアークを高速制御することが難しい。本ソフトスイッチ ング DC-DC コンバータの製品適用に際して，PWMのパ ルス幅が狭まると ta もおのずと短くなる制御を採用してい る。従って, 小出力ではフルブリッジ高周波インバータは ハードスイッチング PWM に近い状態で動作している。

図 13 の $300 \mathrm{~A}$ 出力 TIG アーク溶接用直流電源は IGBT のスイッチング周波数が $60 \mathrm{kHz}$ となっており, 従来ハード スイッチング PWM 高周波絶縁型方式 DC-DC コンバータ 電源に比べ，その容積で $50 \%$, かつ質量で 48\%低減され, 大幅な小型軽量化が図られている。また，ゼロ電圧ソフト スイッチング方式のためスイッチング周波数の高周波数化 が実現され, 出力サイド直流リアクトルの自己インダクタ ンス $\mathrm{L}_{2}$ を小さくできるため, TIG アークスタート性が大幅 に改善されると共に，スイッチング周波数の高周波数化に 伴う制御速度の向上によりアークの安定性が増すなど，溶 接性能が大幅に向上している。

\section{6. あとがき}

以上，本論文では入力サイド DC バスライン直列追加ス イッチと DC バスライン並列ロスレススナバコンデンサか らなる極めて簡単なアクティブ補助共振スナバを付加した 電圧給電フルブリッジソフトスイッチング PWM 高周波イ ンバータを用いた高周波絶縁型 DC-DC コンバータ回路卜ポ ロジーを提案し, その回路動作原理とその特徵を述べた。本 DC-DC コンバータの試作実験での性能評価及び TIG アー ク溶接機用高性能電源の実用化開発を行った。

本新方式高周波卜ランス絶縁・電流変換型ソフトスイッ チング DC-DC コンバー夕回路のユニークな特徵をまとめ ると以下のとおりである。

（1） DC バスライン直列追加スイッチと DC バスライン 並列ロスレススナバコンデンサからなるアクティブ補助共 振 DC リンクスナバを追加するだけのシンプルなフルブリッ ジ高周波インバータを用いた高周波トランス絶縁型 DC-DC コンバータの全てのアクティブスイッチはソフトスイッチ ングが可能であり，スイッチング周波数が約 $10 \mathrm{kHz}$ を超え ると，スイッチング損失低減効果があることを実験デー夕 で定量的に明らかにした。

(2) 新方式ソフトスイッチング PWM DC-DC コンバー 夕回路は, 高周波トランスの 1 次側低電流サイドの主回路に 挿入する DC バスライン直列追加スイッチの導通損失がわ ずかに発生する。実用的観点からは, 高周波卜ランス 1 次 側回路に流れる電流が 2 次側回路の電流よりも小さくなる 低電圧・大電流直流出力対応の電源システムに適している。 
(3) 新方式ソフトスイッチング DC-DC コンバータの 制御回路は, 従来の PWM 信号生成回路を若干修正するた けでよく，一般に市販されているスイッチングレギュレー 夕 PWM 制御 IC $(\mu \mathrm{PC} 494)$ も使用可能であり制御回路が 簡便である。

（4）電圧給電フルブリッジ高周波ソフトスイッチング PWM インバータのスイッチング周波数を高めても, 高周 波インバータ回路部つまりパワーデバイス部（インバータ ブリッジアームスイッチと DC バスライン直列追加スイッ チ）のスイッチング損失が，10 kHz 以上のスイッチング周 波数域では従来型ハードスイッチング高周波インバータに 比べ減少する。一方，スイッチング周波数の高周波数化に より高周波トランスや直流リアクトルが小型化でき, 応用機 器の小型軽量化が可能となっている。また，スイッチング 周波数の高周波数化に伴いスイッチング DC-DC コンバー 夕の制御速度が向上し, 電源応用機器の性能が改善できる。 TIG アーク溶接機においても，大幅な小型軽量化が図れる と共に，アークスタート性とアーク安定性などの溶接性能 が大幅に改善された。

今後は，高周波用 IGBT, IEGT スーパージャンクション MOSFET, ESBT 新構造パワーデバイスや, 次世代新素材 高周波半導体パワーデバイスであるカスコード SiC-JFET や SiC-SBD の本新方式 DC-DC コンバータ回路への適用及 び低電圧・大電流に適した高周波同期整流回路の開発を行 なっていきたい。さらに，三相アクティブ PWM 整流回路 いわゆる三相 PFC コンバータとの組み合わせによる高調波 ライン電流の低減と総合力率向上を図った TIG 溶接機用ソ フトスイッチング DC-DC コンバータシステム開発にも取 り組んでいく所存である。

(平成 16 年 11 月 29 日受付, 平成 17 年 9 月 29 日再受付)
Bridge High-Frequency Link DC-DC Power Converter Operating and Conduction Losses", Proc. IEE-UK International Conference on Power Electronics and Variable-Speed Drives, pp.483-488 (1994-10)

( 7 ) O.D. Patterson and D.M. Divan: "Pseudo-Resonant Full Bridge DC/DC Converter", Proc. IEEE-PESC (Power Electronics Specialist Conference), Vol.2, pp.424-430 (1987)

(8) M. Michihira and M. Nakaoka: "A Novel Quasi-Resonant DC-DC Converter using Phase-Shifted Modulation in Secondary-Side of HighFrequency Transformer", Proc. IEEE-PELS(Power Electronics Specialists Conference), Vol.1, pp.100-105 (1996-6)

(9) M. Michihira, T. Funaki, M. Nakaoka, and K. Matsu-ura: "A Novel quasiresonant DC-DC converter using phase-shift PWM control at secondary side of high-frequency transformer", JSPE Trans., Vol.21, No.2, pp.78-87 (1996-12) (in Japanese)

道平雅一・舟木 剛・ 中岡睦雄・松浦虔士：「2 次側位相シフト PWM 制御を行う新しい部分共振形 DC-DC コンバータ」, JSPE 論文誌, 21, 2, pp.78-87 (1996-12)

10) S. Sato, S. Moisseev, M. Ishitobi, E. Hiraki, and M. Nakaoka: "HighEfficient High Frequency Linked Zero Voltage Soft Switching PWM DC/DC Power Converter with ON/OFF-Assisted Synchronous Rectifier Scheme", IEEJ Trans. IA, Vol.123, No.12, pp.1414-1421 (2003-12) (in Japanese) 佐藤伸二・モイセエフセルゲイ・石飛 学・平木英治・中岡睦雄:「2 次側アシストソフトスイッチ高周波リンク PWM DC-DC コンバー 夕」, 電学論 D, 123, 12, pp.1414-1421 (2003-12)

(11) S. Moisseev, S. Harada, and M. Nakaoka: "Novel Soft-Switching PhaseShift PWM DC-DC Converter”, JSPE Trans., Vol.28, pp.107-116 (2003-3) (in Japanese)

モイセエフセルゲイ・浜田 聡・中岡睦雄:「新しいソフトスイッチン グ位相シフト PWM DC-DC コンバータ」, JSPE 論文誌, 28, pp.107-116 (2003-3)

12) K. Morimoto, T. Doi, H. Manabe, M. Nakaoka, N.A. Ahmed, H.W. Lee, E. Hiraki, and T. Ahmed, "Next Generation High Efficiency High Power DC-DC Converter incorporating Active Switch and Snubbing Capacitor Assisted Full-Bridge Soft-Switching PWM Inverter with High Frequency Transformer for Large Current Output", Proc. IEEE-APEC, pp.1549-1555, Austin, USA (2005-3)

(13) Japan Welding Society: "Fundamentals of Welding Engineering", p.25, Tokyo (1962) (in Japanese)

日本溶接協会偏：「溶接技術の基礎」,p.25 (1962)

(14) J.F. Lancaster: "The Physics of Welding", p.136, Oxford (1984)

\section{文献}

（1）電気学会編：「高周波共振形スイッチング電源方式と応用技術の動 向」,電気学会技術報告, (II 部), 第 443 号 (1992-11)

(2) 電気学会編：「パワーエレクトロニクス機器の電磁波ノイズ」, 電気 学会技術報告, 第 545 号 (1995-5)

(3) S. Hamada, S. Moisseev, O. Koudriavtsev, and M. Nakaoka: "Double Two Switch Forward Soft Switching PWM DC-DC Converter", IEEJ Trans. IA, Vol.123, No.2, pp.121-130 (2003-2) (in Japanese)

浜田 聡・Moisseev Serguei $\cdot$ Koudriavtsev Oleg ·中岡睦雄 :「ダブル 2 石フォワードソフトスイッチング PWM DC-DC コンバー夕」, 電学 論 D, 123, 2, pp.121-130 (2003-2)

(4) S. Nagai, S. Sato, M. Yamamoto, E. Hiraki, and M. Nakaoka: "Effective Improvement of DC Busline Voltage Utilization Factor in Two SwitchAuxiliary Quasi-Resonant DC Link Snubber Assisted Three Phase Voltage Source Type Soft- Switching PWM Inverter", IEEJ Trans. IA, Vol.123, No.6, pp.710-716 (2003-6) (in Japanese)

長井伸一郎·佐藤伸二·山本真義·平木英治·中岡睦雄 : 「2 石補助共振 DC リンクスナバを用いた三相電圧形ソフトスイッチング PWM イン バー夕の直流電圧利用率改善」, 電学論 D, 123, 6, pp.710-716 (2003-6)

(5) N. Hoshi and K. Oguchi: "Control Schemes for Auxiliary Switches of Three-Phase PWM Resonant Snubber Inverters", IEEJ Trans. IA, Vol.123, No.4, pp.343-351 (2004-4) (in Japanese)

星 伸一・大口國臣, 「三相 PWM 共振スナバインバータの補助ス イッチ制御法」, 電学論 D, 124, 4, pp.343-351 (2004-4)

(6) S. Hamada and M. Nakaoka: "Saturable Inductor-Assisted ZVS-PWM Full-

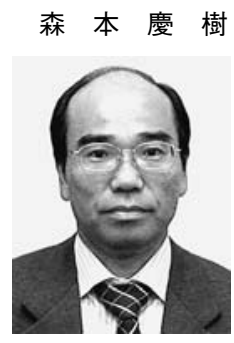

（正員）1982 年姬路工業大学電気工学科卒業 (現在 兵庫県立大学工学部)。同年大阪变圧器 (株) (現在 （株）ダイヘン）に入社。現在，溶接機事業部第一 技術部部長。主に，アーク溶接機用スイッチング 電源の開発に従事。2005 IEEE-IAS IATC (International Appliance Technical Conference) Paper Award 受賞。Kyungnam University の EESRC の研究協 力, パワーエレクトロニクス学会評議員歴任, パ ワーエレクトロニクス学会会員。

土 井 敏 光 (正員) 1985 年同志社大学電気工学科卒業。同年

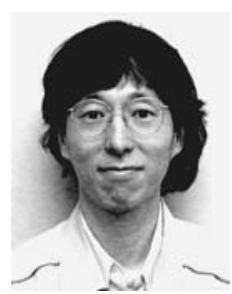
大阪変圧器（株）(現（株）ダイヘン）に入社。現 在, 溶接機事業部第一技術部インバー夕電源開発 グループ長。主に，アーク溶接機用スイッチング 電源の開発に従事。2005 IEEE-IAS IATC (International Appliance Technical Conference) Paper Award 受賞。パワーエレクトロニクス学会会員。 
真 鍋 陽 彦 (正員) 1997 年 3 月徳島大学大学院工学研究科電 気電子工学専攻修士課程修了。同年 (株) ダイヘ ン入社, 現在に至る。主に, アーク溶接機用スイッ チング電源の開発に従事。2004 年電気関係学会 関西支部連合大会電気学会優秀論文発表賞, 2005 IEEE-IAS IATC (International Appliance Technical Conference) Paper Award など受賞。

Tarek Ahmed (Student Member) He received his M.Sc. degree in

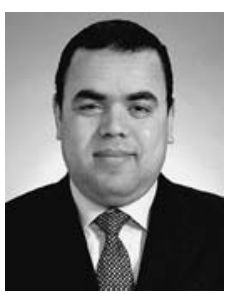
electrical engineering from the Electrical Engineering Department, Faculty of Engineering, Assiut University, Assiut, Egypt in 1998. He is currently working toward the Ph.D. degree in the Power Electronic System and Control Engineering Laboratory, the Division of Electrical and Electronic Systems Engineering, the Graduate School of Science and Engineering, Yamaguchi University, Yamaguchi, Japan. He is an Assistant Lecturer in the Electrical Engineering Department, Faculty of Engineering, Assiut University, Egypt. His research interests are in the new applications of advanced high frequency resonant circuits and systems with the renewable energy related soft switching PWM rectifier and sinewave PWM inverter power conditioner. He is a student-member of the Institute of Electrical and Electronics Engineers of USA (IEEE-USA), the Institute of Electrical Engineering and Installation of Engineers (IEIE-Japan), the Institute of Electrical Engineers (IEE-Japan) and Japan Institute of Power Electronics (JIPE). He was the recipient of prize paper awards from Kansai Branch Institute of Electrical Engineers of Japan (IEE-J) in 2003, 2005 and in 2004 and the student award from IECON 2004.

平 木 英 治（正員） 1990 年 3 月大阪大学大学院基礎工学研

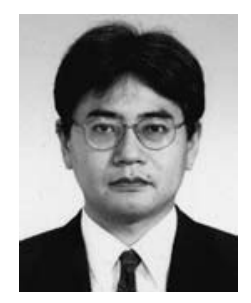
究科博士前期課程電気工学専攻修了。同年マツダ (株) 技術研究所。1995 年山口大学電気電子工学科 助手。工学博士。電気学会新型ソフトスイッチン グ電力変換回路と応用機器技術調査専門委員会幹 事補佐。ソフトスイッチング電力変換システムを 中心とするパワーエレクトロニクスに関する研究. 教育に従事。2005 IEEE-IAS IATC Paper Award 受 賞。IEEE，パワーエレクトロニクス学会（JIPE）の各正会員。
李

鉉 雨 (Member) He received the B.E. degree in Electrical

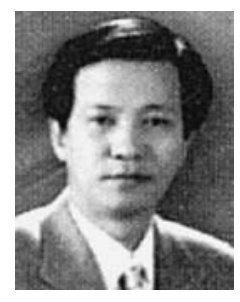
Engineering from Dong-A University, Pusan, Korea in 1979 and received the M.S. degree in Electrical Engineering from Yuing-Nam University, Kyungbook, Korea in 1984 and the Ph.D. (Dr-Eng) degree in Electrical Engineering from Dong-A University, Pusan, Korea in 1992. Since 1985 he has been with the Division of Electrical Electronics Engineering, Head director and supervisor of The Electrical Energy Saving Research Center and Innovation Technology Center of Automation Production, Kyungnam University, Masan, Korea, Professor. He got 2004 KIPE-ICPE, 2004 ICGMS, 2005 IEEE-IAS IATC Paper Award. He is interested in the area of power electronics and new energy related power generation and power storage system. He is a member of the KIEE, KIPE, JIEE,JIPE and IEEE.

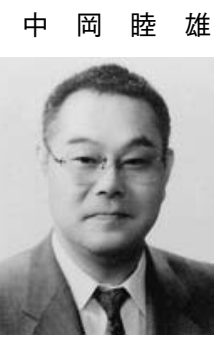

(正員) 大阪大学大学院工学研究科・博士課程電 気工学専攻修了。神戸大学工学部, 電気電子工学 科 /大学院自然科学研究科 $\cdot$ 博士後期課程 $\cdot$ 生産 システム科学専攻勤務を経て, 山口大学工学部, 電気電子工学科/大学院理工学研究科電気システ 厶工学専攻名誉教授, 慶南大学大学院 EE, SRC (Kyungnam University) 教授。アドバンスト・パ ワーエレクトロニクスとエネルギーエレクトロニ クスに関する教育と研究に従事。工学博士。兵庫県科学技術井植賞, 医科学技術賞, 2001 IEE-UK. Premium Paper Award, 2003 IEEE-IAS James Melcher Paper Prize Award，2004，2005 年電気設備学会論文賞， 2004 KIPE-ICPE and 2004 ICEMS Best Paper Awards な゙゙受賞。IEEEIES Japan Chapter Chairman, 電気通信エネルギー技術専門委員, 電子 情報通信学会, 電気設備学会, 日本太陽エネルギー学会, JIPE, KIPE, IEE-Korea，IEEE などの各正会員。 